\title{
CNSL Concentration and Natural Dyes Effects in Formulation of Botanical Pesticide on Sitophilus zeamais and Maize Seed Quality
}

\author{
Dian Astriani *, Wafit Dinarto, Aji Jatmiko \\ Agrotechnology Department, Faculty of Agroindustry, Yogyakarta Mercu Buana University, Km.10 Wates \\ Street, Yogyakarta, Indonesia \\ *Email: astrianidian67@gmail.com
}

\begin{abstract}
Maize is an important commodity in Indonesia and is vulnerable to maize weevil (Sitophilus zeamais) during storage which can cause a 100\% yield loss. Chasew Nut Shell Liquid (CNSL) is a botanical pesticide able to control S. zeamais. Increasing CNSL efficiency and effectiveness requires additional adjuvants, such as solvents and dyes. Natural dyes addition is intended to provide seed markers. This study aimed to determine the best CNSL and natural dye formulation to control maize weevil and maintain maize seeds quality during storage. The research was conducted from August to October 2018 at the Agronomy Laboratory, Faculty of Agroindustry, Yogyakarta Mercu Buana University. The research was a single factor consisted of seven treatments with four replications arranged in a completely randomized design (CRD). Treatments were combinations of CNSL concentrations with the addition of natural dyes from suji leaf and teak leaves with one untreated control. The results of the research showed that CNSL as a seed treatment botanical pesticide could cause mortality and suppress $S$. zeamais populations and maintain the quality of maize seeds during storage for 12 weeks. Treatments with 20\% CNSL formulation concentration and the addition of natural dyes both leaf pleomele or teak leaves could cause higher mortality and push down more populations and also could better maintain seed quality than 10 and $0 \%$ CNSL formulation concentrations.
\end{abstract}

Keywords: maize seed, Sitophilus zeamais, CNSL concentration, natural dye.

\section{Introduction}

Maize is an important crop due to its nutrition contents, including protein, fats, fibers, and especially its carbohydrate contents which are similar to rice (78.9\%) [1]. Maize is also the third most consumed staple food after wheat and rice in the world. Besides, maize has contributed to 40 $50 \%$ of livestock feed raw material. At least 7.8 million ton is needed by feed industries and 2.5 million tons for breeders from a total of 19.4 million tons in 2018 and these demands have increased by up to $16 \%$ for both industries in 2019 [2]. Besides previously stated industries, maize is used in energy industries as raw material for ethanol and biofuel. Due to the vast use of maize, there is merit to increase national maize production to fulfill industry demands [3].

Yield production can be increased by intensification and extensification programs. However, implementing extensification programs in Indonesia is challenging due to remaining areas are marginal areas which require extensive planning in implementing adequate technology to produce sufficient yield [4]. Intensification programs are more reliable in these situations. Maintaining available seeds in storage is important; however, seed storage is time-limited due to several factors such as seed initial source and storage environments [5]. Maize weevils (Sitophilus zeamais) is an important maize pest able to cause damage to the field and off-field. Maize weevils have been reported to decreased yield up to $100 \%$ [6], [7], [9], and decrease seed germination to $43 \%$ after 3 months of storage [8]. 
Chemical insecticide treatments are used to control maize weevil during storage. However, continuous chemical insecticide use can leave residues on seed and harm the environment. Thus, using safe and effective bioinsecticide from plants may alternatives to chemical insecticide. Cashew nutshell extracts are sided products from industries, not fully used, and possess potential as bioinsecticides. Solutions obtained by pressing fresh cashew nut shells contain 25-30\% of CNSL consisted of $60-90 \%$ anacardic acid and $10 \%$ cardol. Anacardic acid is contacted toxic and has been reported to cause mortality against insect pests and inhibit egg hatching [11], [12]. Previous researches have shown $20 \%$ concentration of CNSL resulted in effective control against maize weevil when applied as seed treatments and 10-20\% concentration resulted in no significant differences when treated as bioinsecticides [17], [18].

The adjuvant is added to insecticide formulation to increased their effectiveness and safety measures. Color dyes are added to seed treatment formulation to differ consumption to planting material seeds. In this study, we used an ethanol solution and natural dyes. There is a vast number of works of literature that explore dye molecules from natural materials, such as plant leaves; due to their consideration as safe and easy and cheap to obtain [13]. Suji leaves (Dracaena angustifolia) and teak leaves (Tectona grandis) are common natural food dye materials due to their content of chlorophyll and $\beta$-carotene respectively when extracted with ethanol [14], [15]. Young teak leaves have been reported to contain anthocyanins which are a safe food color pigment that results in the color blue, purple, violet, magenta, red and orange to various plant organs [15]. The use of natural dye limits on cosmetics is about 5-15\% [16]. Therefore, there is merit to determine an effective seed treatment formulation between CNSL as an active ingredient, ethanol as a solvent, and natural dyes to manage maize weevil populations.

\section{Research Method}

The research was conducted from August to October 2018 at the Agrotechnology lab of Yogyakarta Mercu Buana University.

\subsection{CNSL solution formulation}

CNSL extract was mixed with ethanol with a ratio of 1:1. The solution was then added with natural dyes. Natural dyes used in the study were suji and teak leaves. Suji leaf dye was obtained by dissolving $100 \mathrm{~g}$ of suji leaves with $300 \mathrm{ml}$ of distilled water [19], while teak leaf dye from 30 $\mathrm{g}$ of teak leaves dissolved in $150 \mathrm{ml}$ of solvent [20]. Natural dyes were added until reached $10 \%$ of the CNSL formulation volume.

\subsection{Contact toxicity, food toxicity, population growth water content, and seed germination bioassays}

All maize seed using throughout this study was Bima variety of seeds. Contact and food toxicity tested in this study. Contact toxicity was tested by treating 7-15 day old maize with 0.02 $\mathrm{ml} \mathrm{CNSL} \mathrm{formulations.} \mathrm{Mortality} \mathrm{was} \mathrm{observed} 24$ hours later. Food toxicity was observing the mortality of 10 maize weevils infested on $100 \mathrm{~g}$ of maize seed previously treated with $5 \mathrm{ml}$ of CNSL formulation. Before infested with maize weevils, treated maize seed was air-dried. Maize weevil mortality with calculated using formula (1).

$$
\text { Actual mortality }(\%)=\frac{\sum \text { dead insects }}{\sum \text { total insect sample }}
$$


If mortality in control treatments were between $5-20 \%$, then mortality was corrected using formula (2) [21]. Control mortality less than 5\% was ignored, while experiments were repeated if mortality more than $20 \%$.

$$
\text { Corrected mortality }(\%)=\frac{A-C}{100-C} \times 100 \%
$$

$\mathrm{A}=$ moratlity at treatment

$\mathrm{C}=$ mortality at control

Maize seeds in storage tests were treated as in the food toxicity test. The seed was placed in plastic bags with 5 maize weevils. Bags were sealed at left for 12 weeks. Maize weevil imago population, seed weight, and water content decrease, and seed germination was observed.

Water content measurement was done before and after storage by sampling $\pm 5 \mathrm{~g}$ of seeds from all treatments. Seeds were dried by placing a seed into a $130^{\circ} \mathrm{C}$ oven for 4 hours. After that, seeds were placed in a desiccator for 15 minutes to cool. Water content percentage was calculated using formula (3) [22]:

$$
\begin{aligned}
& \quad \text { Seed water content }(\%)=\frac{(\mathrm{M} 2-\mathrm{M} 3)}{(\mathrm{M} 2-\mathrm{M} 1)} \times 100 \% \\
& \mathrm{M} 1=\text { Container mass }(\mathrm{g}) \\
& \mathrm{M} 2=\text { Container mass }+ \text { seed mass before oven }(\mathrm{g}) \\
& \mathrm{M} 3=\text { Container mass }+ \text { seed mass after oven }(\mathrm{g})
\end{aligned}
$$

Seed germination before and after storage was done by germinating 100 seed in a germination container. Seeds that germinated were count from day 1 until day 7. Seed germination was calculated using formula (4) [23]:

$$
\text { Seed germination }(\%)=\frac{\sum \text { number of germinating seeds }}{\sum \text { total seeds tested }} \times 100 \%
$$

\subsection{Statistical analysis}

This study was done using a Completely Randomized Design (CRD) with 1 factor and 4 replications for every 7 treatments. Treatments used in this study were concentration combinations between CNSL solutions and natural dyes. Treatments used in this study were CNSL $0 \%$ with suji leaf dye, CNSL $0 \%$ with teak leaf dye, CNSL $10 \%$ with suji leaf dye, CNSL $10 \%$ with teak leaf dye, CNSL 20\% with suji leaf dye, CNSL 20\% with teak leaf dye, and untreated control. All results from the toxicity test, food toxicity test, storage test, water, and water content were tested using an ANOVA. Results that indicated significant differences were then tested using a Duncan Multiple Range Test. All tests were done at $\alpha=0.05$.

\section{Results and Discussion}

\subsection{Contact and food toxicity}

Results demonstrated that CNSL formulation possessed contact and digestive toxicity (Table 1). CNSL at $10 \%$ and $20 \%$ resulted in $100 \%$ maize weevil mortality either with suji or teak leaf dyes addition. CNSL formulation contact toxicity was consistent with previous findings where CNSL provided contact toxicity against Sitophilus spp. with CNSL LC50 value of $11.1022 \%$ [24]. Contact insecticide can be used against sucking type or chewing type like maize weevil, due to these insecticides enters mechanism into the body of the insect through the cuticle. Recent research has shown that insecticide penetration is also possible through the respiratory system by laterally spreading of accumulated active ingredient on integuments [25]. 
CNSL formulation at $10 \%$ or $20 \%$ at all dye addition resulted in $>80 \%$ mortality at food toxicity bioassay (Table 1). Mortality increased correspondingly to CNSL concentration. Previous research found LC50 of CNSL food toxicity was 4.5040\% [18] which were consistent with previous findings that CNSL at low concentration was able to cause mortality against caterpillars and aphids [26].

High CNSL toxicity against maize weevils is caused by its high content of anacardic acid which can reach $90 \%$. Anacardic acid content in CNSL is an affected extraction process. It has been reported that mechanic extraction without heating resulted in higher anacardic acid levels [10], [27]. Anacardic acids are phenolic lipids, chemical compounds found in cashew nutshells (Anacardium occidentale). As a derivative of urushiol, they also cause an allergic skin rash on contact known as urushiol-induced contact dermatitis. It is partially miscible with ethanol and ether, but nearly immiscible with water. Anacardic acid chemical structure is a mixture of several closely related organic compounds. Each consists of a salicylic acid substituted with an alkyl chain that has 15 or 17 carbon atoms. The alkyl group may be saturated or unsaturated; anacardic acid is a mixture of saturated and unsaturated molecules [28]. Anacardic acid (2-hydroxy-6-alkylbenzoic acid) inhibits prostaglandin enzyme synthesis; thus, disrupting insect physiological and reproduction systems and providing control against too small pest insects, such as aphids and spider mites [29], [34].

In addition to CNSL toxicity due to its anacardic acid and kardol, teak and suji leaf dyes were able to cause low mortality also due to their chemical content. Teak leaves to contain anthraquinones, lignin derivatives, anthratectone, and naphthatectone [30]. The research demonstrated that teak leaf extracts caused to stomach and intestine injury on male white mice [30], [31]. Although suji leaves have not been reported to possess insecticidal properties, previous research showed suji leaf to contain several active compounds such as flavonoids, saponins, steroids, and essential fats which contribute as antioxidants agents, anti-inflammatory agents, and antibacterial agent toward Mycobacterium tuberculosis and Streptococcus pneumoniae [32].

Table 1

CNSL formulation contact and food toxicity against maize weevil imago

\begin{tabular}{|c|c|c|}
\hline \multirow{2}{*}{ CNSL formulation } & \multicolumn{2}{|c|}{ Maize weevil imago mortality (\%) } \\
\hline & Contact toxicity & Food toxicity \\
\hline CNSL 0\% + suji leaf dye & $10^{\mathrm{ab}}$ & $10^{\mathrm{ab}}$ \\
\hline CNSL $0 \%$ + teak leaf dye & $20^{\mathrm{b}}$ & $20^{\mathrm{b}}$ \\
\hline CNSL $10 \%$ + suji leaf dye & $100^{\mathrm{c}}$ & $80^{c}$ \\
\hline CNSL $10 \%$ + teak leaf dye & $100^{\mathrm{c}}$ & $90^{\mathrm{d}}$ \\
\hline CNSL $20 \%$ + suji leaf dye & $100^{\mathrm{c}}$ & $100^{\mathrm{e}}$ \\
\hline CNSL $20 \%$ + teak leaf dye & $100^{c}$ & $100^{\mathrm{e}}$ \\
\hline Untreated (control) & $0^{\mathrm{a}}$ & $0^{\mathrm{a}}$ \\
\hline
\end{tabular}

Numbers followed by the same letter in the same column are not significantly different based on Duncan's test at $\alpha=0.05$.

\subsection{Maize weevil population growth}

CNSL formulation treated as seed treatment affected the population growth of maize weevils (Table 2). CNSL formulation at $20 \%$ concentration and added with suji and teak leaf dyes resulted in $100 \%$ maize weevil imago mortality. Maize weevil population growth inhibition by CNSL formulation with different solvent has also been reported in previous studies [33]. Population growth was inhibited by CNSL formulation at 10\% added with suji and teak leaves although significantly lower than $20 \%$ (Table 2). Also, incomplete mortality may still cause populations to grow. 
CNSL Concentration and Natural Dyes Effects In Formulation of Botanical Pesticide on Sitophilus Zeamais and Maize Seed Quality

Maize weevil requires 48-51.6 days from eggs to image and can lay more than 150 eggs [35], [36]. Eggs are laid in each seed and hatch to feed on seeds. Pupa develops in seeds and imago will crawl out of seed resulting in large holes on seeds. Low population growth in this study's result may be caused by unfavorable seed water content conditions (9-10\%) for maize weevil growth.

Table 2

Maize weevil imago populations on CNSL formulation treated maize seed after 12 weeks

\begin{tabular}{llcc}
\hline \multirow{2}{*}{ CNSL Formulation } & \multicolumn{3}{l}{ Maize weevil population } \\
\cline { 2 - 4 } & Dead & Alive & Total \\
\hline CNSL 0\% + suji leaf dye & $2.75^{\mathrm{b}}$ & $9.25^{\mathrm{b}}$ & $12.00^{\mathrm{ab}}$ \\
CNSL 0\% + teak leaf dye & $4.00^{\mathrm{b}}$ & $7.50^{\mathrm{b}}$ & $11.50^{\mathrm{ab}}$ \\
CNSL 10\% + suji leaf dye & $7.75^{\mathrm{c}}$ & $2.75^{\mathrm{a}}$ & $10.50^{\mathrm{a}}$ \\
CNSL 10\% + teak leaf dye & $8.75^{\mathrm{cd}}$ & $1.25^{\mathrm{a}}$ & $10.00^{\mathrm{a}}$ \\
CNSL 20\% + suji leaf dye & $10.00^{\mathrm{d}}$ & $0.00^{\mathrm{a}}$ & $10.00^{\mathrm{a}}$ \\
CNSL 20\% + teak leaf dye & $10.00^{\mathrm{d}}$ & $0.00^{\mathrm{a}}$ & $10.00^{\mathrm{a}}$ \\
Untreated (control) & $0.00^{\mathrm{a}}$ & $14.25^{\mathrm{c}}$ & $14.25^{\mathrm{c}}$ \\
\hline
\end{tabular}

Numbers followed by the same letter in the same column are not significantly different based on Duncan's test at $\alpha=0.05$.

\subsection{Maize seed water content}

Maize seed water content is an important factor to maintain seed quality and is recommended to be $<10.1 \%$ for 12 months of storage [37]. All treatments resulted in maize seed water content nearby this recommended water content. Water content before and after storage were not significantly different at all treatment. Seed water content is affected by storage temperature and humidity [38]. Besides, maize weevil infestation is affected by moisture causing increases of storage environment moisture and water content may result in higher maize weevil damage [39].

Table 3

CNSL treated maize seed water content before and after 12 weeks of storage

\begin{tabular}{lll}
\hline \multirow{2}{*}{ CNSL formulation } & \multicolumn{2}{l}{ Water content $(\%)$} \\
\cline { 2 - 3 } & Before storage & After storage \\
\hline CNSL 0\% + suji leaf dye & $10.01 \mathrm{a}$ & $10.17 \mathrm{a}$ \\
CNSL 0\% + teak leaf dye & $10.02 \mathrm{a}$ & $10.17 \mathrm{a}$ \\
CNSL 10\% + suji leaf dye & $9.99 \mathrm{a}$ & $10.19 \mathrm{a}$ \\
CNSL 10\% + teak leaf dye & $10.01 \mathrm{a}$ & $10.20 \mathrm{a}$ \\
CNSL 20\% + suji leaf dye & $10.00 \mathrm{a}$ & $10.27 \mathrm{a}$ \\
CNSL 20\% + teak leaf dye & $9.99 \mathrm{a}$ & $10.28 \mathrm{a}$ \\
Untreated (control) & $10.01 \mathrm{a}$ & $10.31 \mathrm{a}$ \\
\hline
\end{tabular}

Numbers followed by the same letter in the same column are not significantly different based on Duncan's test at $\alpha=0.05$.

\subsection{Maize seed weight decrease}

Maize seed weight was measured before and after 12 weeks of storage. Untreated control demonstrated the highest weight decrease due to maize weevil infestation. Maize weevil grubs are the most damaging life stage to maize seed by leaving holes and been reported to cause up to 55\% damage [35], [36]. Maize seed treated with CNSL formulation resulted in significantly lower weight decrease compared to the untreated control (Table 4). Seeds treated with 20\% CNSL concentration and $10 \%$ CNSL concentration with teak leaf dye had $<1 \%$ of weight decrease. In this study, weight loss was positively correlated with insect damage as having been shown in previous research [40]. 
Table 4

CNSL treated maize seed weight decrease after 12 weeks storage

\begin{tabular}{ll}
\hline CNSL formulation & Seed weight decrease $(\%)$ \\
\hline CNSL 0\% + suji leaf dye & $3.84^{\mathrm{d}}$ \\
CNSL 0\% + teak leaf dye & $2.17^{\mathrm{c}}$ \\
CNSL 10\% + suji leaf dye & $1.67^{\mathrm{b}}$ \\
CNSL 10\% + teak leaf dye & $0.76^{\mathrm{a}}$ \\
CNSL 20\% + suji leaf dye & $0.58^{\mathrm{a}}$ \\
CNSL 20\% + teak leaf dye & $0.57^{\mathrm{a}}$ \\
Untreated (control) & $14.56^{\mathrm{e}}$ \\
\hline
\end{tabular}

Numbers followed by the same letter in the same column are not significantly different based on Duncan's test at $\alpha=0.05$.

\subsection{Maize seed germination}

Maize seed germination was calculated from samples before and after storage. Seed germination was significantly affected by CNSL formulation treatment. CNSL formulation seed treatment was able to decrease maize weevils' adverse effects on seed germination. Dye applications without CNSL solutions were also able to maintain seed germination. Untreated seeds were unable to maintain seed germination $>80 \%$ due to maize weevil damage. Grubs can damage germ structure in seed and reported to decrease seed quality to $43 \%$ after 3-month storage [8], [41], [42]. Maize damaged by maize weevil has been reported to experience inhibited germination [39]. The endosperm is important in supporting embryonic growth by supplying nutrients, protecting, and controlling embryo growth as a mechanical barrier during seed development and germination; thus damage to seeds may induce disrupted germination [43].

Table 5

CNSL formulation treated maize seed germination after 12 weeks of storage

\begin{tabular}{ll}
\hline CNSL formulation & Seed germination $(\%)$ \\
\hline CNSL 0\% + suji leaf dye & $89.00^{\mathrm{b}}$ \\
CNSL 0\% + teak leaf dye & $89.25^{\mathrm{b}}$ \\
CNSL 10\% + suji leaf dye & $90.25^{\mathrm{b}}$ \\
CNSL 10\% + teak leaf dye & $91.75^{\mathrm{b}}$ \\
CNSL 20\% + suji leaf dye & $92.42^{\mathrm{b}}$ \\
CNSL 20\% + teak leaf dye & $92.75^{\mathrm{b}}$ \\
Untreated (control) & $74.75^{\mathrm{a}}$ \\
\hline
\end{tabular}

Numbers followed by the same letter in the same column are not significantly different based on Duncan's test at $\alpha=0.05$.

\section{Conclusion}

Results of this study concluded that (1) CNSL formulation had both contacts and feed toxicity to maize weevil S. zeamais, and addition of natural dyes suji leaf or teak leaf could minorly increase its toxicity; (2) CNSL formulation at a concentration of $20 \%$ with the addition of natural dyes suji leaf or teak leaf were better formulation for controlling maize weevil and maintaining the quality of maize seed for 12 weeks storage.

\section{Acknowledgments}

This study was assisted by the Agroteknologi laboratory, Yogyakarta Mercu Buana University. 
CNSL Concentration and Natural Dyes Effects In Formulation of Botanical Pesticide on Sitophilus Zeamais and Maize Seed Quality

\section{References}

[1] Bantacut T. (2010). Ketahanan Pangan Berbasis Cassava. J. Pangan. 19 (1): 3-13.

[2] Yunita M N. (2019). Kementan: Produksi Jagung Nasional Cukupi Kebutuhan Pakan Ternak. [Internet]. 2019. Available from: https://www.suara.com/news/2019/02/18/.2019.09.05.

[3] Bantacut T, Firdaus R Y \& Akbar T M. (2015). Maize Development for Food Security, Industry and Economy. J. Pangan. 24 (2): 135-148.

[4] Dwiratna S, Bafdal N, Asdak C \& Carsono N. (2018). Study of Runoff Farming System to Improve Dryland Cropping Index in Indonesia. International Journal on Advanced Science, Engineering and Information Technology. 8(2): 390-396.

[5] Purwanti S. (2004). Kajian Suhu Ruang Simpan terhadap Kualitas Benih Kedelai Hitam dan Kuning. J. Ilmu Pertanian. 11(1): 21-34.

[6] Ningsih Y., Salbiah D \& Sutikno A. (2017). Uji Beberapa Tepung Daun Gamal (Gliricidia sepium J) terhadap Hama Sitophilus zeamais. pada Biji Jagung di Penyimpanan. JOM Fapetra UR. 4(1).

[7] Surtikanti (2004). Kumbang Bubuk: Sitophilus zeamais Motsch. (Coleoptera: Curculionidae) dan Strategi Pengendaliannya. J. Litbang Pertanian. 23 (4): 123-129.

[8] Dinarto W \& Astriani D. (2008). Pengaruh Wadah Penyimpanan dan Kadar Air terhadap Kualitas Benih Jagung dan Populasi Hama Kumbang Bubuk (Sitophilus zeamais Motsch). Prosiding Seminar Nasional dan Workshop Perbenihan dan Kelembagaan. Fakultas Pertanian UPN "Veteran" Yogyakarta: 74-80.

[9] Tenrirawe A, Pabbage M S \& Takdir A. (2013). Pengujian Ketahanan Galur Jagung Hibrida Umur Genja. Prosiding Seminar Nasional Serealia: 472-481.

[10] Kardinan A. (2002). Pestisida Nabati Ramuan dan Aplikasi. P.T. Penebar Swadaya, Jakarta.

[11] Kumar P P, Paramashivappa R, Vithayathil P J, Rao P V S \& Rao A S. (2002). Process for Isolation of Cardanol from Technical Cashew (Anacardium occidentale L.) Nut Shell Liquid. J Agric Food Chem. 50: 4705-4708.

[12] Simpen I N. (2008). Isolasi Cashew Nut Shell Liquid Dari Kulit Biji Jambu Mete (Anacardium occidentale L.) dan Sifat Fisik Kimia. J. Kimia. 2 (2): 71-76.

[13] Sofyan N, Ridhova A, Pramono K R O, Yuwono A H \& Udhiarto A. (2018). Visible Light Absorption and Photo-Sensitizing Characteristics of Natural Dye Extracted from Mangosteen Pericarps Using Different Solvents. International Journal on Advanced Science, Engineering and Information Technology. 8 (5): 2059-2064.

[14] Risanto \& Yunisari K D. (1994). Penelitian Pembuatan Serbuk Pewarna Hijau Alami Daun Pandan (Pandanus latifolius H.). Berita Litbang Industri, Balai Penelitian dan Pengembangan Industri, Surabaya. 4 (13): 64-74.

[15] Ati N H, Rahayu P, Notosoedarmo S \& Limantara L. (2006). Komposisi dan Kandungan Pigmen Tumbuhan Pewarna Alami Tenun Ikat di Kabupaten Timor Tengah Selatan, Propinsi Nusa Tenggara Timur. Indonesia. J. Chem. 6 (3): 325-331.

[16] Setyawaty R \& Pratama M R. (2018). The Usage of Jati Leaves Extract (Tectona grandis L.f) as Color of Lipstick. Traditional Medicine Journal. 23 (1).

[17] Astriani D, Dinarto W \& Mildaryani W. (2013). Kajian Toksisitas Minyak Kulit Biji Mete Hasil Ekstraksi Mekanis dan Kimiawi terhadap Sitophilus spp. dalam Penyimpanan Benih Jagung”. Prosiding Peningkatan Produksi Pangan dan Pengelolaan Cadangan Pangan Masyarakat untuk Menjaga Ketahanan Pangan Nasional. Fakultas Agroindustri Universitas Mercu Buana Yogyakarta: 108-115.

[18] Astriani D, Dinarto W \& Mildaryani W. (2013). Kajian Formulasi Cashew Nut Shell Liquid (CNSL) sebagai Pestisida Nabati untuk Perlakuan Benih Jagung terhadap Mortalitas Sitophilus spp. Prosiding Pengembangan Sumber Daya Pedesaan dan Kearifan Lokal Berkelanjutan III: 2-11.

[19] Tama J B, Kumalaningsih S \& Mulyadi A F. (2013). Study of Make Natural Colourant Powder From Suji Leaves (Pleomele Angustifolia N.E.BR.). Study Concentration of Maltodextrin And $\mathrm{MgCO}_{3} . J$. Industri. 2 (1): 73-82. 
CNSL Concentration and Natural Dyes Effects In Formulation of Botanical Pesticide on Sitophilus Zeamais and Maize Seed Quality

[20] Zulfa L, Kumalaningsih S \& Effendi M. (2014). Natural Coloring Agent Extraction From Teak Leaf (Tectona Grandis) (Study of Citric Acid Concentration and Time for Extraction) and Laboratorial Scale Economic-Engineering Analyze. J. Industria. 3 (1): 62-72.

[21] Negara A. (2003). The Use of Probit Analysis for Conjecture Susceptibility Status Spodoptera exigua Food Populations to Deltametrin in Yogyakarta. Informatika Pertanian. 12: 1-9.

[22] Anonymous (1991). Petunjuk Pengawas Benih. Sub Direktorat Pengawasan Mutu dan Sertifikasi Benih, Direktorat Bina Produksi Padi dan Palawija, Direktorat Jenderal Pertanian Tanaman Pangan. Jakarta: 142.

[23] Elias S G, Copeland L O, Mc Donald M B \& Baalbaki R Z. (2012). Seed Testing Principles and Practices. Michigan State University Press.

[24] Astriani D \& Dinarto W. (2013). Uji Toksisitas Minyak Kulit Biji Mete terhadap Hama Bubuk pada Penyimpanan Benih Jagung. Prosiding Pengembangan Sistem Agribisnis Tanaman Pangan dan Hortikultura Guna Menunjang Kedaulatan Pangan.

[25] Roy D N \& Ghosh S M. (1994). The Mechanism of Action of a Contact Insecticide. Bulletin of Entomological Research. 35 (2): 161-170.

[26] Atmadja W R \& Wahyono T E. (2009). Pengaruh Cashew Nut Shell Liquid (CNSL) terhadap Mortalitas Helopeltis antonii Sign. pada Bibit Jambu Mete. Bul. Litro. 17 (2): 66 -71.

[27] Cahyaningrum, A., Setyowati T \& Nur A. (2006). Ekstraksi Cashew Nut Shell Liquid (CNSL) dari Kulit Biji Mete. Ekuilibrium. 5 (1) : 40-45.

[28] Rosen T \& Fordice D B. (2011). Cashew Nut Dermatitis. Southern Medical Journal. 87 (4): 543-546, 1994.

[29] Schultz D J, Olsen C, Cobbs G A, Stolowich N J \& Parrott M M. (2006). Bioactivity of Anacardic Acid against Colorado Potato Beetle (Leptinotarsa decemlineata) Larvae. J. Agric. Food Chem. 54 (20): 7522-7529.

[30] Hamdin C D, Prasedya E S, Utami S W, Galanova D, Saputro D C, Nurrochmad A, Murwanti R, Jupri A \& Sunarpi H. (2019). Acute Toxicity of Indonesian Natural Food Colorant Tectona grandis Leaf Extracts in Wistar Rats. Journal of Medical Sciences: 69-74.

[31] Hendrarti W, Indrisari M, Pasang M \& Nursamsiar (2012). Uji Toksisitas Subkronik Ekstrak Etanol Daun Jati Putih (Gmelina arborea Roxb.) pada Tikus Putih Jantan (Rattus novergicus)". PHARMACY. 9 (3).

[32] Eveline, Jessica \& Siregar T M. (2016). Antimicrobial Activity and Stability of Suji Leaves (Dracaena angustifolia (Medik.) Roxb.) Extract. Proceeding of 3rd International Conference on Research, Implementation And Education of Mathematics and Science, Yogyakarta: 39-44.

[33] Astriani D, Dinarto W \& Sambodo R. (2014). Pengaruh Jenis Pelarut dan Konsentrasi Ekstrak Kulit Biji Mete Terhadap Sitophilus zeamais pada Penyimpanan Benih Jagung". Prosiding SNKP.

[34] Tomawaha J \& Ahmadi N R. (2011). Pemanfaatan Cashew Nut Shell Liquid Sebagai Sumber Fenol Alami Pada Industri. Bulletin RISTRI. 2 (2) : 187-198.

[35] Manueke J, Tulung M \& Mamahit J M E. (2015). Biologi Sitophilus oryzae dan Sitophilus zeamais (Coleoptera; Curculionidae) pada Beras dan Jagung Pipilan. Eugenia. 21 (1): 20-31.

[36] Devi S R, Thomas A, Rebijith K B \& Ramamurthy V V. (2017). Biology, Morphology and Molecular Characterization of Sitophilus oryzae and S. zeamais (Coleoptera: Curculionidae). Journal of Stored Products Research. 73: 135-141.

[37] Arief R, Mursalim, Zakaria B \& Saenong S. (2010). Analisis Hubungan Mutu Benih Jagung dengan Produktivitas". Penelitian Pertanian Tanaman Pangan. 29 (2).

[38] Saenong S, Azrai M, Ramlan A \& Rahmawati (2007). Pengelolahan Benih Jagung. Balai Penelitian Tanaman Serealia, Maros.

[39] Keba T \& Sori W. (2013). Differential Resistance of Maize Varieties to Maize Weevil (Sitophilus zeamais Motschulsky) (Coleoptera: Curculionidae) under Laboratory Conditions. Journal of Entomology. 10 (1) : 1-12. 

and Maize Seed Quality

[40] Oloyede-Kamiyo Q O \& Adetumbi J A. (2017). Relationship between Seed Physical Traits and Maize Weevil (Sitophilus zeamais) Damage Parameters in Selected Quality Protein Maize (QPM) Varieties. Journal of Stored Products Research. 73: 42-46.

[41] Stejskal, Aulicky R \& Kucerova Z. (2014). Pest Control Strategies and Damage Potential of SeedInfesting Pests in the Czech Stores - a Review". Plant Protect. Sci. 50 (4): 165-173.

[42] Surtikanti \& Suherman O. (2003). Reaksi 52 Galur/Varietas Jagung Terhadap Serangan Kumbang Bubuk. Berita Pusat Penelitian dan Pengembangan Pertanian Tanaman Pangan. 26: 3-4.

[43] Yan D, Duermeyer L, Leoveanu C \& Nambar E. (2014). The Functions of the Endosperm During Seed Germination. Plant Cell Physiol. 55 (9): 1521-1533. 